\title{
Towards a world without precedent
}

The turn of every year is an occasion for reflection, the present more so than most. When last did a year begin with the well-advertised possibility of a damaging war within 15 days? Here are some reflections for the research community.

THE belief that science is international is widely shared, but is it also correct? The guiding principle is that discovery is a common endeavour to which all can contribute and in which all may share. Its formal embodiment is the public literature, to which all have access both as potential contributors and as users, but there is more to say than that. Much of the excitement of the past few years has stemmed from the ways in which previously separate groups of users of this common resource have been able physically to mingle with each other, sometimes choosing to collaborate, sometimes deciding not to do so. The tentative arrangements now being made in Germany for the continued support of eastern German research (see page 3) are a poignant reminder that even much-desired changes may cause hardship; some researchers from old East Germany will be generously supported, others no doubt will lose their jobs. And those circumstances will mark the temper of the scientific community in Germany for many years to come.

So how will research, and intellectual life in general, be shaped by the much greater upheavals under way beyond the German frontiers? There is no way of telling, for the upheavals have still to be completed. Yet some things are already clear. First, the scale of physical migration from one place to another is probably greater than at any previous time in human history. More than a million people have fled the Middle East in the past few months, mostly to Egypt, India, Pakistan and the southwest Pacific, yet the more deliberate continuing flight from the Soviet Union will cumulatively have greater consequences. Second, five new legitimately autonomous states have appeared in Central Europe - and may soon be joined by as many more if last week's elections in Yugoslavia are a guide. Third, it is unthinkable that the Soviet Union can hang together except as a loose association of states at one extreme or as a self-destructive despotism at the other.

Mr Mikhail Gorbachev, the Soviet president, has rightly been given credit (by a Nobel committee, among others) for the reshaping of Central Europe, yet he is now much reviled by his supporters of only a few years ago. His error was to seek to combine the posts of head of state and general-secretary of the Soviet Communist Party, whose influence he rightly sought to diminish. To complain that a man who is manifestly so courageous lacked the courage required by logic at a critical juncture must seem churlish, but many of the troubles of the past few years have flowed from that mistake. The danger now is that even Gorbachev will rediscover what his predecessors knew, that only the Party's apparatus is used to running the Soviet Union.

Whatever happens, one loser will be Soviet science. Many have left, are leaving or will leave. Many of those remaining are made less productive than they would be elsewhere by the privations of daily life, regularly shown to be pointless by the now-durable connections with the outside world. Yet economic reform, if it now arrived by magic, would make things worse for many people in research, who would find that the establishments to which they are attached could no longer afford them. That is one reason why the research community elsewhere, in its own long-term interests, should now be prepared to offer what help it can. The republic academies need help, as do universities individually. Sadly, finding places for able researchers and promising students has become an urgent need. It will be a great surprise if it is satisfied before the century is out.

\section{What global treaty?}

The chances of negotiating a convention on greenhouse gases are shrinking.

EVERYBODY will agree that if the threat of global warming is real, it must command more urgent attention than any other contemporary environmental issue. This is not to say that adaptation to much higher average temperatures would be technically impossible, but merely that it would be horrendously expensive in money (from the pockets of prosperous populations) and lives - those of the poorest peoples. That, no doubt, is why there has been a substantial measure of agreement among governments on the sequence of events that should be followed in the negotiation of a greenhouse convention (see page 3 ). Yet optimism about the outcome of this process may be the most serious impediment of success.

The most subtle, but most obdurate, difficulty is that the problem has not been thoroughly talked through. It is customary to say that last year's reports from the Intergovernmental Panel on Climate Change (IPPC) represent what is called a consensus. In the strict sense, this 